\title{
EVALUATING TEACHERS' PERCEPTION ON INTEGRATING ICT IN TEACHING-LEARNING PROCESS
}

\author{
Maryam Yaqoob Khan \\ Research Scholar, \\ Greenwich University, Karachi, Sindh, \\ Pakistan \\ Email: maryam.labyrinth@gmail.com \\ S. Khurram Khan Alwi \\ Associate Professor, \\ Greenwich University, Karachi, Sindh, \\ Pakistan
}

\begin{abstract}
Fast development and change in ICT have prompted the dispersion of innovation in teaching instructions. The motivation behind this assessment is to explore teachers' recognition in incorporating ICT in their educating-learning process. The assessment questions focused to estimating teachers' product use and other instructional devices and materials, inclinations for proficient improvement on data assembling and support, factors that empower instructors' use of innovation, teachers' view of self-adequacy and obstructions that instructors focused upon in the middle of innovation usage in instructing learning process. A populace of 25 instructors at DHA School took part in this overview. The outcome on equipment and programming use demonstrates that lion's share of instructors in the school can't utilize equipment in showing learning process due to primarily deficiency of assets. Teachers who can't utilize ICT as instructional apparatus are 76 percent higher than the individuals who can utilize it. This demonstrates most educators in the school are not incorporating ICT in the course they instruct. In respect of the data and bolster administrations, there is no equivalent help benefit from the specialized help units. DHA School is found as poor by most of the teachers in preparing ICT trainings. The factors that encourage technology are considered highly important to apply ICT in teaching-learning process. Even though, the school teachers have strong positive perception for using ICT in teaching-learning process. Teachers' perception toward ICT usage to increase quality of
\end{abstract}


curriculum and their eventual productiveness is found as significant. This indicates that the teachers realize the productivity in integrating ICT in their professional approach. However, majority of the teachers pointed out that one of the barriers to technology implementation is lack of teachers' technical knowledge and shortage of resources. This shows that equipping the school with ICT related apparatus is not enough for attaining educational modification. Hence, the school should critically focus on teachers' abilities for integrating ICT in whole curriculum to make each subject's lesson interactive and easily understandable by their students.

\section{KEYWORDS}

Evaluating, Teacher perception, ICT, Learning

\section{INTRODUCTION}

Information and communication technology (ICT) are a force that has changed many aspects of the way we live. It is playing a big role in many disciplines like medicine, tourism, travel, business, law, banking, engineering and architecture. The impact of ICT across the past two or three decades has been enormous. The way these fields operate today is vastly different from the ways they operated in the past because of the rapid development of technology. However, in case of education, there seems to have been lack of influence and far less change than other fields have experience (Pramanik, 2011).

But education is one of the most important investments in building human capital in a country and makes a nation technologically innovative and a good path to economic growth. Thus, rapid growth and improvement in ICT have led to the diffusion of technology in education (Gulbahar and Guven, 2008). Educational systems around the world are becoming increasingly pressured to apply the new ICT tools to their curriculum to provide students with the knowledge and skills that they need in the 21st century (Hueand, 2013).

Their use is also underlined by many scholars as a necessity for improving quality in teaching and learning. Over the past decades, governments and education systems around the world have regarded the use of information and communications technologies as an important issue for improving the effectiveness of teaching and learning (Plump, Anderson, Law, \& Qualex, 2009). 
Researchers also reviewed that an intellectual use of ICT for educational purposes yield positive outcomes on the part of students, such as, increased motivation, active learning, providing efficient resources and better access to information (Sahin-Kizil, 2011). Moreover, researchers reviewed that technology has great potential to increase learners' motivation, link learners to various information sources, support collaborative learning, and allow teachers more time for facilitation in classrooms. Integrating ICT into teaching and learning has therefore become a great concern for many educators (Wang and Woo, 2007). Improvement in computers, communication hardware and other mixed media apparatuses give a wide run of tactile jolts. Due to this it is said, I see and I keep in mind, I do and I get it. The movements, reenactments, computer programs bundle to instruct different subject make virtual substances and encounter for the learners, which in turn, offer assistance in making learning a more coordinate, valuable and happy. Learners' self- engaged learning is conceived as the center of great instruction.

Integration of Information and Communication Technologies into teaching and learning process is a growing field. According to different literatures, integration of ICT is necessitated to contribute to the learning process of the students (Cartwright and Hammond, 2003), (Herzig, R. 2004), (Lim and Chin, 2004), (Lim et al., 2003). Integrating ICT into teaching and learning is not a new concept. It may be as old as other technologies such as radios or televisions (Wang and Woo, 2007). However, with the rapid development of emerging technology such as web technology, ICT integration has increasingly attracted the attention of educators. The integration of information and communication technologies can help teachers and students to improve and develop the quality of education by providing curricular support in difficult subject areas. (Gulbahar and Guven, 2008).

Integration has a sense of completeness or wholeness by which all essential elements of a system are seamlessly combined together to make a whole. In education, simply handing out to students a collection of websites or CD-ROM programs is certainly not ICT integration. According to (Earle, 2002) ICT and other crucial educational components such as content and pedagogy are molded into one entity to say that ICT integrated lesson is properly applied.

However, Integration of ICT is not a simple application (Bhasin.B, 2012). This means there are many barriers to apply in the teaching-leaning process. 
Researchers' findings show that teachers have a strong desire for the integration of ICT into education but they encountered many barriers (Bingimlas, K. A., 2009). The major barriers were lack of confidence, competence and assets. Since need of certainty, competence and accessibility have been found to be the basic components of innovation integration in school. ICT assets including hardware and program, successful professionals' improvement, adequate time and specialized bolster require to be provided to instructors. No one component in itself is adequate to supply great educating. In any case, the presence of all components increments of plausibility of amazing integration of ICT in instructing and learning openings. Therefore, it is very critical to assess that perception of teachers in ICT integration in their practical approach.

\section{LITERATURE REVIEW}

The term Information and Communication Technology (ICT) is a broad and comprehensive expression. It is not restricted to the computers or the internet alone. It ranges from the use of FM radio to satellite for communication. (UNESCO, 2002) opines that ICTs are the fundamental building blocks of the present-day society. The contemporary society is highly influenced by ICT in every aspect of life, including education". M.O. Yusuf, (2005) states that the effects are experienced more in the field of education since it has the potential for teachers to transform the teaching methodology to meet individual needs. Today, schools are under pressure to adapt to this technological innovation needs. V.L. Tinio, (2002) express that ICT provide remarkable opportunities for developing countries to enrich their educational system since it can help in acquiring and assimilating knowledge.

Watson, (2001) asserts that ICT has influenced the way people function today, both personally and professionally, which demands change in the educational arena. (N Davis and T. Penni, 1999) \& (C. Lemke and C.C. Edward, 1998) informed that research undertaken worldwide has confirmed that ICT can help to improve student learning by providing better instructional techniques.

\section{ICT integration enhance teaching and learning}

G. R Angadi, (2014) inscribed in his journal about the past traditional methodology that "The application of ICT is creating significant changes in the teaching and learning process. The traditional approach in teaching has stressed on content. For decades course materials were designed around textbooks. Teachers taught the content through lecture method and the activities were 
designed to enforce the content knowledge".

Present day teachers need to create relevant and intriguing learning experiences for their students. Technology provides a remarkable role in making education inclusive since it has the potential to improve educational performance of students. The present-day curricula promote aptitude and performance of the learners, emphasizing on the application of the information rather than factual knowledge. ICT facilitates the dissemination of knowledge based on the contemporary curricula (R. Oliver, 2000).

ICT-enhanced learning stimulates augmented learner involvement. The constructivist method views learning as realistic and learner-centered. ICT is an effective tool in constructivist approach of learning, where teachers can layout simulated and tailor-made learning conditions to students, (D.Lebow, 1993; D. Jonassen, and T. Reeves, 1996). "In this regard, applying educational technology as a constructivist device can help students to display their ideas, express their knowledge, examine, exploit, and process information, in a collaborative learning environment" (Z. Berge ,1998; A. Barron, 1998). "ICTenhanced learning stimulates augmented learner involvement. The constructivist method views learning as realistic and learner-centered. ICT is an effective tool in constructivist approach of learning, where teachers can layout simulated and tailor-made learning conditions to students" (D.Lebow, 1993; D. Jonassen, and T. Reeves, 1996).

For instance, software applications like databases and excel sheets foster inquiry-based learning activities. Multimedia is a powerful tool that assists thinking activities of learners and also helps them to share and express their knowledge. These software applications help students in understanding the concept by doing. It also facilitates in developing an independent approach towards problem -solving. In that sense computers help students in developing high order thinking" (D. H. Jonassen, 1999; G. McMahon, 2009).

Teachers play a crucial role in integrating ICT. The present-day teachers should know not only the content of their subject but also the pedagogy to impart the knowledge effectively by integrating technology. According to (Y. Zhao, \& G. A Cziko, 2001) in order to integrate ICT in teaching teachers must recognize the usefulness of technology, they should believe that the application of technology does not disrupt the classroom climate. Moreover, they should also 
have the confidence to manage technology. Nevertheless, research studies indicate that majority of the teachers do not take advantage of the potential of ICT to promote the quality of learning, even though they have a favorable attitude towards it (E. Smeets, 2005),(G. Alharbi, 2012), (E. Barolli, J. Bushati, and M.B Karamani, 2012), (B. Cubukcuoglu, 2013). ICTs are exerting impacts on pedagogical approaches in the classrooms. Their contribution to changes in teaching practices, school innovation, and community services are considerable "(F. Mikre, 2011).

\section{ICT enhances accessibility to learning}

Education is not just teaching students based on prescribed syllabus in the four walls of a classroom. It has much border objectives, goals as well as other concepts. Hence, Classrooms without borders needs to be the concept of the contemporary education system. ICT is an answer to this concept. It helps to deliver education anytime and from anywhere (U.K.Pegu, 2014).

A. Kok, (2007) observed that using ICT helps students to communicate, share ideas, and work as a team anywhere, anytime. This includes teleconferencing classroom where students around the world are invited to meet together for discussion related to a specific topic. Under such circumstances students besides acquiring knowledge collectively, also share their learning experiences, which enable to express themselves and contemplate on their learning. ICT also helps to involve the students in a global collaborative learning.

The Machinto Project, a K-12 literature-based iEARN program of Backley and Takagi is a good example in this regard. The facilitators of this program use ICT, such as Web conferencing and wikis, to connect students to their peers in other countries and cultures. This also helps in establishing connections and achieving true and meaningful learning. Moreover, it lends purpose to lessons and drives "just-in-time" learning for teachers as well as students as they become co-learners (J.Young, 2002).

Distance education programmes, which are very popular these days gained momentum because of ICT. Mobile technologies and immaculate communications technologies support 24/7 teaching and learning process. The time duration will be utilized within the 24/7 time frame which will be a challenge that educators face in future (J.Young, 2002). Hence, the ICT empowered education system will eventually result in the democratization of 
education, predominantly in developing countries like India. Effectual utilization of ICT for the educational purpose will be able to bridge the digital divide that exists in the nation today.

Since technology is changing constantly, Individuals should have to keep pace with the recent developments in order to access information through ICT (T. Plomp, W. J. Pelgrum, \& N. Law, 2007). ICT helps to reduce communication obstacles like space and time (C. P. Lim and C.S. Chai, 2004). ICTs also make it easy for the development of electronic resources, such as, electronic libraries where the students, teachers and experts are able to access research information and study materials from anywhere at their own pace (I.Bhattacharya, K.

Sharma, 2007), (V. S. Cholin, 2005).

\section{ICT enhancing the learning environment and motivation}

ICT is a powerful tool for promoting educational opportunities. It is transforming the processes of teaching and learning environment by including elements of vitality to the learning atmosphere. Present day education system insists on research, critical thinking, and evaluation skills since students have access to large variety of sources to get information. Hence, the learning environment provided should follow an effective application of knowledge that students are required to master, in order to avoid the attained knowledge being passive (J. D. Bransford R. D. Sherwood, T. S. Hasselbring, C.K. Kinzer \& S. M. Williams, 1990; T.M Duffy, and K.A Randy, 1990). Furthermore, teachers need to encourage students to be active learners so as to engage in active knowledge construction. This entails open-ended learning situations rather than a learning condition which focus on the sheer transmission of facts (A. Collins, 1996; M. J. Hannafin, C. Hall, S. Land, and J Hill, 1994; D. H. Jonassen, K. L Peck, and B. G. Wilson, 1999).

Moreover, ICT can also function as an instrument of curriculum differentiation. It promotes opportunities to modify the learning material and activities to the requirements and capabilities of every individual learner, particularly by giving personalized feedback (T. Mooji, 1999; E. Smeets, t. Mooji et al, 1999; F.E Akele, 2013). As (T. Stoddart, \& D. L. Niederhauser, 2013) emphasize ICT might appeal to an array of educational techniques, ranging from traditional to ingenious.ICTs are also transformational devices, if used effectively, can shift the classroom atmosphere to a learner-centered environment (S.N Amin, 2013; G. R Angadi, 2014). Therefore, it is necessary to equip the classroom with 
computers in order to enhance the learning opportunities for students through different curriculum activities. ICT environment develops the experience of both teachers and students so that they can utilize the learning time effectively (S. Kennewell, J. Parkinson, and H.Tanner, 2000). Hence, ICT-enriched learning is a motivating factor for both teachers and learners (T. Plomp, W. J. Pelgrum, \& N. Law, 2007).

Computers with Internet access can enhance learner motivation since it incorporates the media opulence and interactivity of different ICTs. It gives an opportunity to connect with real people and to get involved in real life situations. This is often stated as a reason influencing "ready adaptors of ICT" (S. Long, 2001; J.Wood, 2004). Consequently, the application of ICT in teaching and learning will not only improve the learning environments but also help next generation for their future lives and careers (S. Wheeler, 2001).

\section{ICT enhancing academic performance}

The relation between ICT integration and student performance has been the topic of research and discussion for the last two decades. (Valasidou, A., Sidiropoulos, D., Hatzis, T., \& Bousiou-Makridou, D. ,2005) Believe that ICT improves the performance of students since technology helps to improve teacher-student interaction. (Kulik, J. A., 2003) Meta-analysis study pointed out that, in general, students who used computer-based learning scored higher than students who learned without computers. ICT integrated learning helps students to grasp the concept better and also retain it for a longer period of time. ICT also help students to develop a positive attitude towards learning since they are engaged in the learning process. Analyzed the international data from the Programme for International Student Assessment (PISA). The findings revealed that there is a significantly positive correlation exist between the availability of ICT and students' performance. However, the correlation becomes weak and insignificant when other student environment factors are taken into consideration. (Woessmann, L., \& Fuchs, T., 2004).

Similarly, (Battle, P. A. J., 1999) studied the correlation between having a home computer and students' academic performance. Approximately 64,300 students in the United States took part in the study. The results revealed that students who have access to a computer at home for educational purposes have performed well in reading and math. Likewise, in a study conducted by (Kulik, J. A., 1994) on 75 students in the United States divulge that students who used 
computer tutorials in Mathematics, Science and Social Studies performed very well in the test. The author also stated that computer tutorials on reading helped elementary students to improve their reading skills.

Li, Y., LeBoeuf, E. J., Basu, P. K., \& Turner, L. H., (2003) opined that -first, web-based instruction presents information in a non-linear style, allowing students to explore new information via browsing and cross-referencing activities. Second, web-based teaching supports active learning processes emphasized by constructivist theory. Third, web-based education is enhanced understanding through improved visualization and finally, the convenience, it could be used anytime, at any place.

This writing audit investigated the effect of ICT in the present-day training framework. ICTs have affected instructive practices to some degree and will increment significantly in future. ICT will turn into an intense operator in changing a few instructive practices. Relentless application and improvement of ICTs in the training framework will affect showing learning process, openness of instruction, propelling students, making an amiable learning condition and enhancing scholastic execution.

ICT mix in training positively affects both instructing and learning process. Innovation has a great deal of effect in the conveyance of lessons or even training on the loose. ICT has the potential for a more extensive availability to instructive assets. Moreover, it upgrades adaptability, so that, understudies can approach adapting regardless of time and land constraints. It can likewise affect the way understudies are educated in the classroom and the way they learn. It rouses the students by making a rich learning condition by giving new chances to the two instructors and understudies. These open doors can affect understudies' scholarly execution and instructive accomplishment. In like manner, more extensive accessibility of good instructive practices and instructive projects, which can be shared through ICT, can upgrade the spread of best training framework.

\section{OBJECTIVES}

1. To evaluate from which hardware or software instructional tools are teachers well acquaint with.

2. To evaluate the information and support resources that teachers used/need.

3. To evaluate the Perceptions of Teachers about use of ICT 
4. To evaluate the barriers to technology usage

5. To inspect the relationship between perception of teachers to integrate ICT and factors that encourage ICT usage

6. To analyze the relationship between teachers' perception toward ICT usage and its productiveness

\section{RESEARCH QUESTIONS}

1. Which ICT assets (programming, instructional apparatuses and materials) do teachers utilize?

2. What are teachers favored techniques for proficient improvement?

3. What are the elements that energize teachers' innovation utilization?

4. What are teachers' discernments in connection to ICT utilization?

5. What are the hindrances that teachers look amid innovation use in the educating-learning process?

6. What is the connection between impression of teachers to coordinate ICT and components that empower ICT utilization?

7. What is the connection between teachers' recognition toward ICT utilization to enhance quality of courses they instruct and their expected productiveness due to ICT usage?

\section{RESEARCH HYPOTHESES}

1. Impact of teachers' attitude and confidence in integrating ICT in their professional teaching approach.

2. Impact of effective leadership and administration has a positive influence in implementing ICT in teaching-learning environment.

3. Impact of availability of ICT technological resources is required for executing appropriate teachers' professional teaching-learning methods.

4. Impact of convenient accessibility of ICT equipment's are necessarily required for ICT's effective integration in teacher's professional approach.

5. Impact of schools' investments on support services of instructional technologies.

6. Impact of eliminating barriers faced by teachers for effective teachinglearning process.

7. Impact of integrating ICT to analyze growth in educating quality and likewise productiveness in curricula.

The study engaged only quantitative data. In this research basically, primary data source was used to gather first-hand information to achieve the objectives 
of the research. The total population is 30 teachers. Thus, the researcher took all these teachers using survey study. Based on the list of teachers in the school, the researcher distributed the questionnaire appropriately to every respondent. Generally, 25 completely answered questionnaires were received for the respondents to articulate the problems highlighted in the respective study. Totally there are 30 teachers in selected department of DHA School of Teachers Education. The total population of this study is 25 . Since the population is manageable, it is census study. In this research, primary data source was collected through questionnaire. To collect data through questionnaires, I distributed them to the responding teachers thyself as they were easily available in one work place.

The information collected from questionnaire was organized and statistical computations were to explore the relationships among different variables. Responses from the closed ended questions were fed into computer and analyzed using SPSS 20.0 software. Descriptive statistics was applied to compute the percentage and frequency distribution of the respondents on the variables.

DATA ANALYSIS \& FINDINGS

Section A: Hardware and Software usage

The ability to use hardware and software in teaching-learning process.

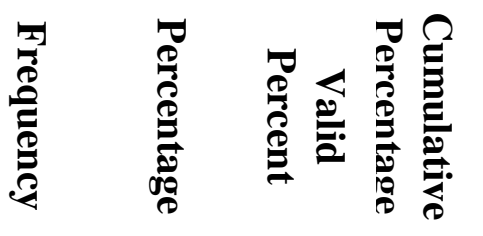

Yes / No

1) Do you have computer in your department?

$18 / 7 \quad 72 / 28 \quad 72 / 28 \quad 100$

2) Do you use instructional animations, slideshows, Films (video, CDs, DVD etc)

$6 / 19 \quad 24 / 76 \quad 24 / 76 \quad 100$

3) Have you ever used Computer Projector system as instructional tools?

$10 / 15 \quad 40 / 60 \quad 40 / 60 \quad 100$

4) Do you use Television/Video or slide projector as instructional tool?

$9 / 16 \quad 36 / 64 \quad 36 / 64 \quad 100$ 
5) Are you able to use Microsoft Office? $\quad 15 / 10 \quad 60 / 40 \quad 60 / 40 \quad 100$

6) Are you able to search information using search engines like Google?

$20 / 5 \quad 80 / 20 \quad 80 / 20 \quad 100$

7) Have you ever got any experience sharing from different institutes?

$1 / 24 \quad 4 / 96 \quad 4 / 96 \quad 100$

Total

$25 \quad 100 \quad 100$

\section{Description:}

According to the table, majority of teachers have the opportunity of getting computers in their respective department. However, some teachers lack the technical skill for utilizing resources provided by school administration. Regarding the course taught by teachers, who cannot use instructional animations, slide shows and films to add creativity to their lessons for students' better comprehension are $76 \%$ higher than those who can easily utilize them. They complain that main obstacles are low attention by school's management and shortage of recourses to apply such instruments; like lack of audio-visual rooms and du to unconvertible classrooms to show slide shows and films. To use instructional tools the computer-projector system is one of the important infrastructures. Furthermore, majority of teachers are incapable of using Television / video or slide projector as instructional tools in teaching-learning process.

Teachers who cannot use this technology are higher in number in comparison. The ones facing knowledge gap complain that school should give attention. Two-third of the school teachers is able to use Microsoft offices but they are some gaps in similar applications. Rests of the teachers suffer due to shortage of computers for practice and limited continuous trainings. Majority of the teachers are able to search information using search engine, like Google, Bing, yahoo. Teachers who can search engine are $96 \%$ higher than those who cannot utilize such facilities. The reasons mentioned by the teachers who cannot search information using search engine are the unavailability of network expansion to all departments, knowledge gap, shortage of computers in departments and lack of successive trainings as the technology is changing drastically. Those who can search also confirmed that they search information regarding the course they teach. This indicated that even though teachers are to search information from internet which can help teaching-learning process, they are limited to 
apply any information to their students due to constraints they face in hardware.

In regard to the experience sharing, a large margin of the teachers has got no such experience sharing with other different institutes in how they integrate ICT in their teaching approaches except for one, who got some exposure from abroad. Generally, most of the teachers are unable to use hardware in teaching learning process due to primarily shortage of resources. This signifies that most teachers are bound from integrating ICT in their professional approach easily.

\section{Section B: Information and Support Resources}

Information and support resources used in teaching-learning process

\begin{tabular}{lllllll}
\hline & & & & & \\
\end{tabular}

\section{Description:}

The respondents used a five-point Likert-type scale (i.e. very good, good, satisfactory, very poor, poor) to rate their level of agreement on 3 statements about information and support resources used in teaching-learning process. According to the table, almost all teachers in DHA School believe that internet is helpful as information resource in teaching-learning. Only 5 teachers responded that they have a skill gap in utilizing this facility and lack from taking decision of incorporating this application in their teaching-learning process. 
Most of the teachers confirm that school's contribution on employing technical support units in ICT sector is good to satisfactory. However, few teachers consider it to be poor. This indicates that there is no equal support service by the technical support units in ICT sector.

Few teachers agree that contribution of the school in preparing ICT trainings is from very good to satisfactory, but some are not satisfied by the administration's efforts. Similarly, school's preparatory ICT trainings classes are appreciated by many teachers but a large number of employees do not consider them up to the mark. Basically, ICT trainings are conducted on computers rather than on how to integrate ICT to each course; hence teachers having negligible computer skills undermine such activities.

\section{Section C: Factors encourage technology usage}

Factors that encourage technology usage in teaching-learning process

\section{Frequency}

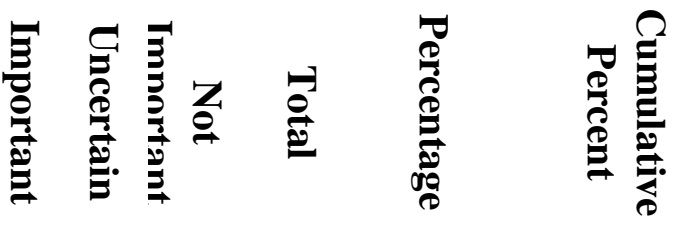

11) Motivating and rewarding teachers to use ICT in 25

$25 \quad 100$

100 instructional activities?

12) Investment of the school on teachers training programs for Instructional technologies? 13) Investments of the school on the support services of instructional technologies? 14) Providing support for the projects towards the expansion 25 of instructional technologies 15) Integrating ICT into each subject during curriculum 25 $25 \quad 100$ 100 25 25

$25 \quad 100$

100 designing 


\section{Description}

The respondents used a three-point Likert-type scale (i.e. Important, uncertain, not important) to rate their level of agreement on 5 statements about factors that encourage technology usage in teaching-learning process. Teachers strongly believed that usage of instructional technologies makes it easier to prepare course materials. This indicates that if good and interactive materials are prepared which students can access and easily understand the course. As a result, teachers' productiveness increases.

\section{Section D: Perception of teachers about use of ICT}

Perception of teachers about ICT usage in teaching-learning process

\section{Frequency}

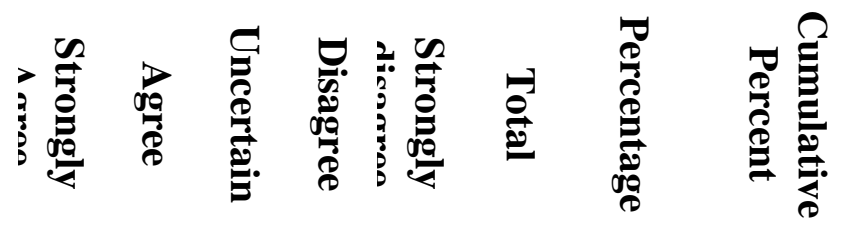

16) Use of ICT for instructional purposes is important rather than printed materials only. 17) Creating awareness raising on the opportunities that

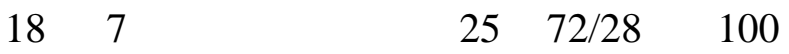
computers offer.

18) I am interested to use ICT in class activities more $\begin{array}{lllll}22 & 3 & 25 & 88 / 12 & 100\end{array}$ effectively.

19) ICT supported teaching can make 214 $25 \quad 84 / 16$ 100 
20) Students can actively pursuit knowledge if ICT integrated in curriculum 214 $25 \quad 84 / 16 \quad 100$ areas.

21) Use of instructional technologies can increase the quality of 20 courses.

22) Usage of instructional technologies make it easier to prepare course materials (assignments, handouts, etc)

23) Using instructional technologies make 232 $25 \quad 92 / 8$ 100 teachers more productive

\section{Description}

The respondents used a five-point Likert-type scale (i.e. strongly agree, agree, uncertain, disagree, strongly disagree) to rate their level of agreement on 8 statements to investigate perception of teachers about use of ICT. Teachers strongly believe the usage of instructional technologies makes it easy to prepare course materials. This indicates that if good and interactive materials are prepared students can access and easily understand the course. As a result, teachers' productiveness increases.

Section E: Barriers to Technology Usage

The barriers that teachers face to use technology during teaching-learning process

\section{Frequency}

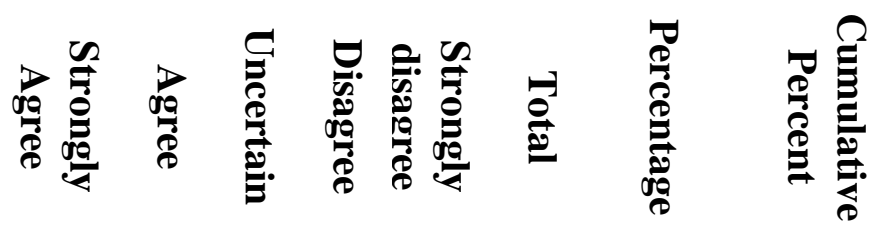


24) Inefficient time

to prepare materials

based on

technology due to

lack of technical

knowledge

25) Lack of

teachers' technical

knowledge to

prepare materials

$10 \quad 15$

$25 \quad 100$

100

based on

technology

26) Shortage of

resources like

computer, projector

etc

27) Inefficiency of school computer lab and audio-visual

rooms

28) Inefficiency of

school computer

laboratory, media

(printer, scanner,

etc)

29) Shortage of

computers used or

available for

teachers.

30) Absence of

motivation and

reward system for

ICT usage.

31) Inadequacy of computers used by

learners
25

1

15

$25 \quad 40 / 60 \quad 100$

$25 \quad 100 \quad 100$

25

$25 \quad 100 \quad 100$

25

$25 \quad 100 \quad 100$

$25 \quad 100 \quad 100$

$25-100-100$

25

$25 \quad 100 \quad 100$

25

$25 \quad 100 \quad 100$ 
32) Deficiency of support services in

ICT usage for 25

25

100

100

teaching -learning.

33) Lack of interest

of teachers in

integrating ICT in

their professional

$25 \quad 100$

100

teaching-learning

methods

\section{Description}

The respondents used a five-point Likert-type scale (i.e. strongly agree, agree, uncertain, disagree, strongly disagree) to rate their level of agreement on 10 statements about barriers to adopt technology. Inefficient time to prepare materials based on technology and lack of interest of teachers in ICT usage for teaching-learning statement is not found as major barrier. These statements indicate that teachers have interest to use their time to integrate ICT in to teaching-learning process if the major barriers are solved.

According to the analyzed result, DHA School teachers featured that one of the hindrances to innovation execution is absence of instructors' specialized learning to plan materials in light of innovation. This demonstrates the outfitting the school with ICT isn't sufficient for achieving instructive change. The presentation of ICT into training requires an equivalent level of development in different parts of instruction. The deficiency of the innovation courses offered to instructors and the absence of motivating forces for empowering innovation are further obstructions to ICT use.

To apply ICT in showing learning, accessibility of recourses is one of the key elements. In any case, the result demonstrated that in spite of the fact that educators in school will utilize ICT assets and they are confronting issues with availability to ICT assets and absence of preparing openings. Deficiency of PCs required by students is additionally found as hindrance and this ruins understudies from effectively adjusting innovation amid ICT incorporation in instructing learning process.

The outcome discoveries likewise show that instructors have a powerful urge for the coordination of ICT into training however they experienced numerous 
barriers. Nobody segment is adequate for giving great educating. Notwithstanding, the nearness of all parts increment the likelihood of phenomenal incorporation of ICT in instructing learning openings. Along these lines, the school ought to give ICT assets including equipment and programming; powerful experts' advancement and specialized help gave to instructors and to make condition for understudies in ICT utilization.

\section{DISCUSSION}

The motivation behind this examination is to explore instructor's recognition on coordinating ICT in educating learning process. The examination questions center around the territories of programming use and also other instructional apparatuses and materials, inclinations for proficient advancement on data assembling and support, factors that empower instructors' use of innovation, educators' impression of self-adequacy and hindrances that educators looked amid innovation use in their educating learning method. Greater part of the educators can't utilize equipment in showing learning process due to fundamentally deficiency of assets. This demonstrates most educators in the school are not incorporating ICT in the course they instruct.

A large portion of the instructors in the school concur that the commitment of the school on utilizing specialized help units in ICT division regards attractive. Hardly any instructors are reacted that the commitment is extremely poor. The respondents' rate on Very Good and poor is the same. This shows there is no equivalent help benefit by the specialized help units in ICT division. DHA School is found as poor by a large portion of the educators in getting ready ICT trainings. Scarcely any instructors concur the commitment of the school in getting ready ICT trainings is great. In any case, the trainings are basically on PC fundamentals as opposed to on the most proficient method to incorporate ICT to each course.

Lion's share of the educators in the school can seek data utilizing web search tool. Instructors who can web index are higher in number when contrasted with the individuals who can't utilize it. The reasons specified by the instructors who can't look data utilizing internet searcher are the inaccessibility of system development to all offices, learning hole, a smaller number of PCs in offices and absence of successive trainings as the innovation is evolving drastically. The review demonstrates the elements that support innovation running at high rate and are critical to apply ICT in instructing learning process. There is critical 
connection between instructors' recognition towards ICT reconciliation into Teaching-learning process and the elements that empower ICT use. Its addition will build nature of courses educated and their productiveness.

To apply ICT in showing learning, accessibility of recourses is one of the key components. Be that as it may, the outcomes demonstrated that in spite of the fact that instructors in DHA School will utilize ICT assets, they are confronting issues with availability to ICT assets and absence of preparing openings. Generally, in spite of the fact that instructors expressed that they put stock in the advantages of the combination of ICT, yet do not have the capacities of utilizing it legitimately.

\section{RECOMMENDATION}

It is vital to inspire and compensating educators to utilize ICT in instructional exercises. Technology should be joined along with educational programs configuration with a specific goal to apply it effortlessly and the school should likewise give consideration in making agreeable condition which persuades to utilize this innovation.

\section{REFERENCES}

Akele, F. E. (2014). Information and Communication Technology as Teaching and Learning Space for Teachers of English Language in Schools. Journal of Emerging Trends in Educational Research and Policy Studies, 5(1), 100.

Alharbi, G. (2012). Primary school teachers' perceptions regarding ICT usage and equipment in Kuwait. Journal of International Education Research, 8(1), 55.

Anderson, J. E. (2002). Information and Communication Technology in Education-A Curriculum for Schools and Programme of Teacher Development UNESCO.

Barolli, E., Bushati, J., \& Karamani, M. B. Factors That Influence in the Adoption of ICT in Education.Battle, P. A. J. (1999). Home computers and school performance. The information society, 15(1), 1-10.

Bhasin, B. (2012). Integration of Information and Communication Technologies in Enhancing Teaching and Learning. Contemporary educational technology, 3(2), 130-140.

Bhattacharya, I., \& Sharma, K. (2007). India in the knowledge economy-an electronic paradigm. International Journal of Educational Management, 21 (6), 543-568.

Bingimlas, K. A. (2009). Barriers to successful integration of ICT in teaching and learning environments. A review of literature. Eurasia Journal of Mathematics 
Science and Technology Education. 5(3), 235-245.

Cartwright, V., \& Hammond, M. (2003). The integration and embedding of ICT into the school curriculum: more questions than answers. In ITTE 2003 Annual Conference of the Association of Information Technology for Teacher Education, Trinity and All Saints College, Leeds.

Cholin, V. S. (2005). Study of the application of information technology for effective access to resources in Indian university libraries. The International Information \& Library Review, 37(3), 189-197.

Collins, A. (1996). Design issues for learning environments. Internationa perspectives on the design of technology-supported learning environments, 347-361.

Cubukcuoglu, B. (2013). Factors enabling the use of technology in subject teaching. International Journal of Education and Development using Information and Communication Technology, 9(3), 50.

Davis, N., \& Tearle, P. (1999). The research and development of an international core curriculum for information and communications technology in teacher training. In Society for Information Technology \& Teacher Education International Conference (pp. 887-892). Association for the Advancement of Computing in Education (AACE).

Duffy, T. M., \& Knuth, R. A. (1990). Hypermedia and instruction: Where is the match? In Designing hypermedia for learning (pp. 199-225). Springer, Berlin, Heidelberg.

Earle, R. S. (2002). The Integration of instructional technology into public education: Promises and challenges. Educational Technology, 42 (1), 5-13.

G. R Angadi, (2014). "An Effective Use of ICT Is a Change Agent for Education". Online International Interdisciplinary Research Journal, 4, 516 -528.

Gulbahar, Y., \& Guven, I. (2008). A Survey on ICT Usage and the Perceptions of Social Studies Teachers in Turkey. Educational Technology and Society, 11(3), 37-51.

Hannafin, M. J., Hall, C., Land, S., \& Hill, J. (1994). Learning in open-ended environments: Assumptions, methods, and implications. Educational Technology, 34(8), 48-55.

Hue, L. T., \& Ab Jalil, H. (2013). Attitudes towards ICT Integration into Curriculum and Usage among University Lecturers in Vietnam. International Journal of Instruction, 6(2), 53-66.

Jonassen, D. H., \& Reeves, T. C. (1996). Learning with technology: Using computers as cognitive tools, DH Jonassen (Ed.), Handbook of research for educational communications and technology, 693-719.

Jonassen, D. H. (1999). Computers and Mindtools for Schools: Engaging Critical Thinking

Jonassen, D. H., Peck, K. L., \& Wilson, B. G. (1999). Learning with technology: A constructivist perspective. 
Kennewell, S. (2000). Developing the ICT Capable School/Steve Kennewell, John Parkinson, Howard Tanner. Florence: Routledge.

Kok, A. (2007). ICT Integration into Classrooms. Unpublished literature review.

Kulik, J. A. (2003). Effects of using instructional technology in elementary and secondary schools: What controlled evaluation studies say. Arlington, VA: sri International.

Kulik, J. A. (1994). Meta-analytic studies of findings on computer- based instruction. Technology assessment in education and training, 1, 9-34.

Lebow, D. (1993). Constructivist values for instructional systems design: Five principles toward a new mindset. Educational technology research and development, 41(3), 4-16.

Lemke, C., \& Coughlin, E. C. (1998). Technology in American Schools: Seven Dimensions for Gauging Progress. A Policymaker's Guide.

Li, Y., LeBoeuf, E. J., Basu, P. K., \& Turner, L. H. (2003). Development of a webbased mass transfer processes laboratory: System development and implementation. Computer Applications in Engineering Education, 11(1), 2539.

Lim, C. P., \& Chai, C. S. (2004). An activity-theoretical approach to research of ICT integration in Singapore schools: Orienting activities and learner autonomy. Computers \& Education, 43(3), 215-236.

Long, S. (2001). Multimedia in the art curriculum: Crossing boundaries. International Journal of Art \& Design Education, 20(3), 255-263.

McMahon, G. (2009). Critical thinking and ICT integration in a Western Australian secondary school. Journal of Educational Technology \& Society, 12(4), 269.

Mikre, F. (2011). The roles of information communication technologies in education: Review article with emphasis to the computer and internet. Ethiopian Journal of Education and Sciences, 6(2), 109-126.

Muir-Herzig, R. G. (2004). Technology and its impact in the classroom. Computers \&Education 42(2), 111-131.

Mooij, T. (1999, August). Guidelines to pedagogical use of ICT in education. In 8 th Conference of the 'European Association for Research on Learning and Instruction'(EARLI). Göteborg, Sweden.

Oliver, R. (2000). Creating meaningful contexts for learning in web-based settings. Proceedings of open learning, 53-62.

Pegu, U. K. (2014). Information and communication technology in higher education in India: Challenges and opportunities. International Journal of Information and Computation Technology, 4(5), 513-518.

Plomp, T., Pelgrum, W. J., \& Law, N. (2007). SITES2006-International comparative survey of pedagogical practices and ICT in education. Education and Information Technologies, 12(2), 83-92.

Plump, T., Anderson, R., Law, N., \& Qualex, A. (2009). Cross-national information 
and communication. Technology policies and practices in education (2nd edition).

Primanik, R. (2011). Information and Communication Technology (ICT) among School-going Children: A Technological Intervention. Journal of Education and Practice.

Şahin-Kizil, A. (2011). Teachers Attitudes Towards Information and Communication Technologies (ICT). 5th International Computer \& Instructional Technologies Symposium, Firat University, ELAZIĞ - Turkey.

Smeets, E. (2005). Does ICT contribute to powerful learning environments in primary education? Computers \& Education, 44(3), 343-355.

Smeets, E. F. L. (1999). The impact of information and communication technology on the teacher.

Stoddart, T., \& Niederhauser, D. (1993). Technology and educational change. Computers in the Schools, 9(2-3), 5-23.

UNDP, U. (2001). World Bank and WRI (2000). World Resources, 87-102.

V. L.Tinio (2016)"ICT in Education: UN Development Programme." Retrieved via: www.eprmers.org on 24.01 (2002).

Valasidou, A., Sidiropoulos, D., Hatzis, T., \& Bousiou-Makridou, D. (2005). Guidelines for the design and implementation of e-learning programmes. In Proceedings of the IADIS International Conference IADIS E-Society, 27.

Wang, Q., \& Woo, H. L. (2007). Systematic Planning for ICT Integration in Topic Learning. Educational Technology \& Society, 10 (1), 148-156.

Watson, D. (2001). Pedagogy before technology: Re-thinking the relationship between ICT and teaching. Education and Information technologies, 6(4), 251-266.

Williams, S. M., Kinzer, C. K., Hasselbring, T. S., Sherwood, R. D., \& Bransford, J. D. (2012). Anchored instruction: Why we need it and how technology can help. In Cognition, Education, and Multimedia (pp. 129-156). Routledge.

Wheeler, S. (2001). Information and Communication Technologies and the Changing Role of the Teacher Journal of Educational Media, 26.

Woessmann, L., \& Fuchs, T. (2004). Computers and student learning: Bivariate and multivariate evidence on availability \& use of computers at home \& at school.

Wood, J. (2004). Open minds and a sense of adventure: How teachers of art \& design approach technology. International Journal of Art \& Design Education, 23(2), 179-191.

Yusuf, M. O. (2005). "Information and communication education: Analyzing the Nigerian national policy for information technology. International Education Journal Vol. 6(3), 316-321.

Young, J. (2002). The 24-hour professor. The Chronicle of Higher Education, 48(38), 31-33

Zhao, Y., \& Cziko, G. A. (2001). Teacher adoption of technology: A perceptual control theory perspective. Journal of technology and teacher education, 9(1), 5-30. 